\title{
Democracy related units in Social Studies Curriculums Based on Self-regulation Strategies: A Comparison of Turkey and Germany
}

\author{
Cevat Eker ${ }^{1}$, Ayhan İncirci ${ }^{2}$ \\ ${ }^{1}$ Asst. Prof., Ereğli Faculty of Education, Bulent Ecevit University, Zonguldak, Turkey \\ ${ }^{2} \mathrm{PhD}$ Student, Faculty of Education, Düzce University, Düzce, Turkey \\ Correspondence: Ayhan İncirci, PhD Student, Faculty of Education, Düzce University, Düzce, Turkey.
}

Received: July 4, 2016 Accepted: July 20, $2016 \quad$ Online Published: August 1, 2016

doi:10.11114/jets.v4i9.1712 URL: http://dx.doi.org/10.11114/jets.v4i9.1712

\begin{abstract}
This study aimed to compare the units related to democracy concept of Social Studies Curriculums applied in Federal Republic of Germany and Republic of Turkey. The goals of the study indicated in Democracy related unit in Social Studies Curriculum in Turkey is examined comparatively with North Rhine-Westphalia State of Germany based on the learning strategies depending on Zimmerman (1998) and Pintrich (2000)'s learning model built on self-regulation. Firstly, literature review of the descriptive research method was used and then, documents were categorized, classified and sorted out using document analysis technique. The derived data of the both countries were compared by the appropriateness to self-regulation strategies. As a result of the study, the democracy related units applied by the curriculums of both countries are found appropriate to students' gaining self-regulation strategies and also at the end of the study; some suggestions are stated to be able to use the educational environment more effectively in terms of self-regulation strategies.
\end{abstract}

Keywords: Republic of Turkey and Federal Republic of Germany, self-regulation, democracy, social studies curriculum, comparison, document analysis

\section{Introduction}

Development of democracy is to a large extend depends on education. It was John Dewey who firstly discussed the relationship between democracy and education in his very well-known work "Democracy and Education" (Dewey \& Archambault, 1974). According to him, education needs to direct the way of student's life and the methods used to teach and learn need to be accordingly. Dewey states that this can only be obtained by integrating the information learned in school with activities related to real life and occupations (cited in Geray 1993), because democracy demands students thinking and communicating through democratic tools, owning democratic values and democratic behavioral patterns.

In the present day, with the changes in educational paradigms, teacher centered education has become students centered (Incirci, 2016). Naturally, it has become more and more important for students to be able to act independently, think critically, be responsible for his/her own learning, be affective on his/her learning process and have ability for self-assessment (Çetin, 2015; Suzuki, 2015; Brown, Andrade \& Chen, 2015; Hwang, Hsu, Shadiev, Chang \& Huang, 2015). This consideration brought into prominence of self-regulation studies. Self-regulation, involves student's own ideas, feelings and the way he/she used them to gain his/her academic achievements (Zimmerman, 1998). Students' acquisition of learning strategies based on Zimmerman (1998) and Pintrich (2000) facilitates them to obtain expected behaviors. Pintrich (2000) identifies the self-regulation strategies as a constructivist process in which students form and control their own cognition and behaviors, identify their own goals, while Risemberg and Zimmerman (1992) define them as stating goals, create and developing strategies to achieve these goals and supervising these activities. According to Zimmerman (2000), self-regulation strategies are the strategies which students think that they will be useful to attain the desired goals and skills.

The actions and operations aiming knowledge or skills containing psychomotor and cognitive processes to be gained by students are the components of self-regulation based strategies (Pintrich, 2000). Self-regulation based learning strategies are divided into groups as; cognitive strategies and resource controlling strategies. Cognitive strategies involve students' 
cognitive processes and behaviors used for accomplishing a given task or to carry out learning (Boekaerts, 1998). Therefore, students' learning the democracy integrated units depends on their desire to the lesson. Their desire is conditioned to be aware of the deficient points in encountered conditions or events. The feeling of this perceivable deficiency comes together with the feeling of curiosity and by means of the curiosity the students endeavor and spend time to learn. It is vital for students to be aware of the tools help them to learn; how, when and where to use the information learned, any psychomotor or cognitive strategies direct them to learn besides being able to use motivation tools appropriately to verify the learning completely (Durmaz \& Avaroğulları, 2016; Loima \& Vibulphol, 2016). When all these mentioned taken together; students who can keep up with the technological changes and developments, renew $\mathrm{him} / \mathrm{h}$ erself, produce and share information have become the necessity of the $21^{\text {st }}$ century (Egnor, 2013). In this context, examination of different countries and preparing shared curriculums can be considered as significant. One of the ways to examine different countries is via Comparative Education. Comparative Education is comparing reciprocally the education systems, education policies and applications of different countries. Comparative studies carried out on the education systems of the countries' present different cultural perspectives, opinions, ways of thinking while enable us to observe our own country as if an external observer (Hantrais, 1995). When the literature is analyzed, there are studies (Garner, 1990; Pintrich \& De Groot, 1990; Zimmerman \& Martinez Pons, 1990; Miller, 2000; Wolters, Pintrich, \& Karabenick, 2003; Beisthuizen, 2008; Arsal, 2009; Pasternak \& Whitebread, 2010; Cheng, 2011; Bembenutty, 2011; Kingir, Taş, Gök \& Vural, 2013; Bono \& Bizri, 2014; Ebadi \& Shakoorzadeh, 2015; Riva \& Ryan, 2015) about teaching self-regulation strategies to students and improving them. Nevertheless, it is detected that there is not any study about comparison of two countries' curriculums based on self-regulation strategies.

In this study, it is aimed to compare the curriculums of Federal Republic of Germany which is one of the European Union countries and Republic of Turkey which maintains the efforts to be a member of the union and has a dep-rooted history in the Anatolia in sense of the democracy related goals about self-regulation strategies. Because the states in Republic of Germany prepare their own curriculums there is not a specific curriculum and there is not Social Studies subject in every state, North Rhine-Westphalia was chosen for the comparison as being the most crowded state of the country and having Social Studies subject in the schools. The unit "Living Democracy" of the Republic of Turkey and "How Does Democracy Work?" of the Federal Republic of Germany within the Social Studies Curriculums are compared in the study.

\section{Method}

Two analyses of the qualitative methods were used in this comparative education research; descriptive and document analyses. These analyses are used to describe the phenomena and conditions while trying to describe the relations between variables (Philips \& Schweisfurth, 2014; Crossly \& Watson, 2003; Çepni, 2010; Yıldırım \& Şimşek, 2011). Only the official curriculums of both countries were taken into consideration throughout the research MEB (2009) for Turkey and Ministerium für Schule und Weiterbildung des Landes Nord-Rhein-Westfalen (URL-1) for Germany. Documents reflect the feelings, ideas, and instructions of the writer or writers which may also help to understand human interactions as societal events. For the validity and reliability of the study the themes were defined separately using the same scale (Table 3 ) by the researchers and $85 \%$ of agreement was assured on the findings of the study.

\section{Results}

The findings of the democracy related units' goals based on self-regulation strategies related are in this part of the study.

\subsection{Distribution of the Democracy Related Goals in Turkey}

In this part of the study, the findings obtained from distribution of the democracy related goals of the Social Studies Curriculum in Turkey. The obtained data are presented in table 1.

Table 1. Distribution of the Democracy related goals in Turkey

\begin{tabular}{|c|c|}
\hline $\begin{array}{l}\text { Subject } \\
\text { Grade } \\
\text { Topic }\end{array}$ & $\begin{array}{l}\text { Social Studies } \\
7^{\mathrm{Ln}} \\
\text { Living Democracy }\end{array}$ \\
\hline 㳫 & $\begin{array}{l}\text { 1. Notices the changes and continuity of the domination in Turkish States throughout the history. } \\
\text { 2. Gives examples for the properties of Republic of Turkey which takes its place in the second provision of the } \\
\text { 3. Anstitution. } \\
\text { 4. Argues the administration of Republic of Turkey within the frame of the concepts of legislation, executive } \\
\text { 5. Analyses the educational and social activities in his/her environment with regards to principles of democracy. }\end{array}$ \\
\hline
\end{tabular}

When table 1 is examined, it can be seen that the "Living Democracy" unit of the $7^{\text {th }}$ Grade Social Studies Curriculum includes five democracy related goals. 


\subsection{Distribution of the Democracy related goals in North Rhine-westphalia}

In this part of the study, the findings obtained from distribution of the democracy related goals of the Social Studies Curriculum in North Rhine-Westphalia (NRW) of the Federal Republic of Germany. The obtained data are presented in table 2.

Table 2. Distribution of the Democracy related goals in North Rhine-Westphalia

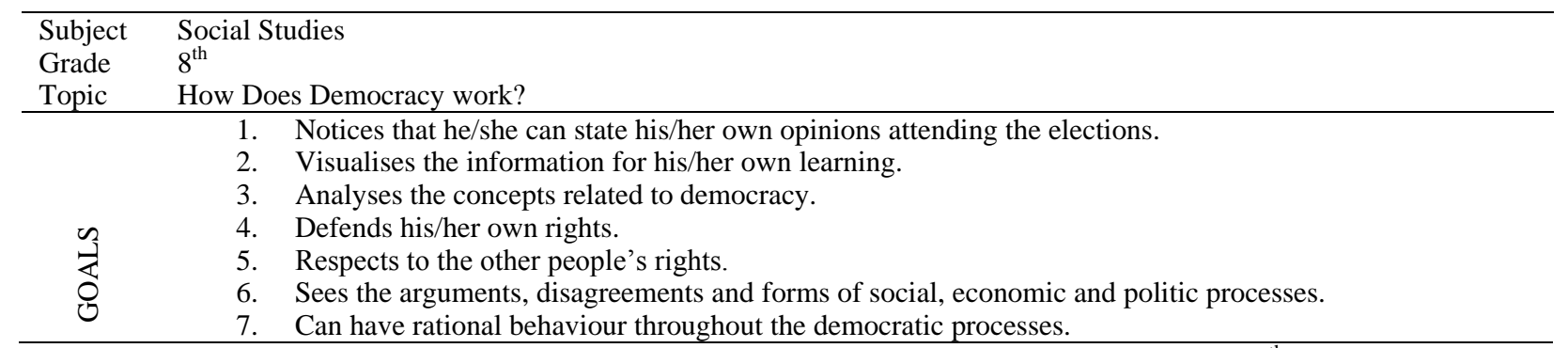

When table 2 is examined, it can be seen that the "How does Democracy Work?" unit of the $8^{\text {th }}$ Grade Social Studies Curriculum includes seven democracy related goals.

\subsection{Comparison of Democracy related goals in Turkey and Germany}

Comparative data including appropriateness of democracy related goals to the self-regulation strategies are presented in this part of the study. The data obtained are presented in table 3.

Table 3. Comparison of Democracy related goals based on Self-Regulation Strategies in Turkey and Germany

\begin{tabular}{|c|c|c|c|c|c|}
\hline \multirow{2}{*}{\multicolumn{2}{|c|}{ Self-Regulation Strategies }} & \multicolumn{2}{|c|}{ TURKEY } & \multicolumn{2}{|c|}{ GERMANY } \\
\hline & & $\mathrm{f}$ & $\%$ & $\mathrm{f}$ & $\%$ \\
\hline \multirow{4}{*}{ 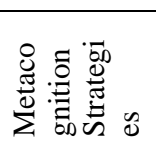 } & Planning & 2 & 8.70 & 2 & 7.70 \\
\hline & Setting Goals & 1 & 4.35 & 2 & 7.70 \\
\hline & Monitoring and Self Assessment & 2 & 8.70 & 4 & 15.40 \\
\hline & Arrangement & - & - & 2 & 7.70 \\
\hline \multirow{3}{*}{ లี } & Repeating & 3 & 13.00 & 1 & 3.85 \\
\hline & Articulation and interpretation & 4 & 17.40 & 2 & 7.70 \\
\hline & Organisation & 2 & 8.70 & 2 & 7.70 \\
\hline \multicolumn{2}{|c|}{ Motivational Strategies } & 1 & 4.35 & 3 & 11.55 \\
\hline \multicolumn{2}{|c|}{ Regulation of effort and endeavour } & 1 & 4.35 & 3 & 11.55 \\
\hline \multicolumn{2}{|c|}{ Resource administration Strategies } & 3 & 13.00 & 2 & 7.70 \\
\hline \multicolumn{2}{|c|}{ Searching for help Startegies } & 1 & 4.35 & 1 & 3.85 \\
\hline \multicolumn{2}{|c|}{ Time and studying environment regulation strategies } & 3 & 13.00 & 2 & 7.70 \\
\hline \multicolumn{2}{|c|}{ TOTAL } & 23 & 100 & 26 & 100 \\
\hline
\end{tabular}

In table 3, the distribution of self-regulation related goals are presented. It is detected that all of the democracy related goals are appropriate for self-regulation strategies in Social Studies Curriculum of Turkey. When the table 3 is examined according to the Self-regulation strategies it is seen that maximum number of the goal is "Articulation and interpretation" strategy with the frequency of $4(17,40 \%)$. Respectively, repeating strategy (3 goals, 13.00\%), Resource administration Strategies (3 goals, 13.00\%), Time and studying environment regulation strategies (3 goals, 13.00\%), Planning Strategy (2 goals, 8.70\%), Monitoring and Self-Assessment (2 goals, 8.70\%), Organizing Strategy (2 goals, 8.70\%), Setting Goals Strategies (1 goal, 4.35\%), motivational strategies (1 goal, 4.35\%), Regulation of effort and endeavor strategies (1 goal, $4.35 \%)$, Searching for help Strategies (1 goal, $4.35 \%)$ are following by the frequencies. It is seen that there is not any strategy related to "Arrangement" strategy.

It is found that all of the democracy related goals are appropriate for self-regulation strategies in NRW's Social Studies Curriculum. When the table 3 is examined according to the Self-regulation strategies it is seen that maximum number of the goal is "Monitoring and Self-Assessment" strategy with the frequency of $4(15,40 \%)$. Respectively, motivational strategies (3 goals, 11.55\%), Regulation of effort and endeavor strategies (3 goals, 11.55\%), Planning Strategy (2 goals, 7.70\%), Setting Goals Strategies (2 goals, 7.70\%), Arrangement Strategies (2 goals, $7.70 \%$ ), Articulation and interpretation (2 goals, 7.70\%), Organizing Strategy (2 goals, 7.70\%), Resource administration Strategies (2 goals, $7.70 \%)$, Time and studying environment regulation strategies (2 goals, 7.70\%), Repeating Strategy (1 goal, 3.85\%), Searching for help Strategies (1 goal, 3.85\%) are following by the frequencies.

Here are some examples of self-regulation related goals within the curriculums applied in Turkey and NRW of Germany: 
Table 4. Some Examples from the Curriculums of Both Countries

\begin{tabular}{ll}
\hline Examples from Turkey & Examples from NRW of Germany \\
\hline Argues about the effects of political parties, & Notices that he/she can state his/her own opinions \\
non-govermental organisations, media, and students in the attending the elections. / Metacognition Strategies - \\
process of decision making and agenda. / Cognitive \\
Strategies - Articulation and interpretation. \\
Analyses the educational and social activities in his/her \\
environment with regards to principles of democracy. I
\end{tabular}

\section{Discussion and Suggestions}

The results obtained from this study compared the democracy related goals of Social Studies Curriculums of Tukey and NRW of Germany based on the self-regulation strategies are presented below.

In Turkey democracy related unit "Living Democracy" takes place in the curriculum of 7th grade Social Studies, while in NRW of Germany, the unit "How Does Democracy Work?" takes place in the curriculum of 8th grade Social Studies. There some studies (Gašević, Dawson and Siemens, 2015; Şişman, 2011; Erdener, 2009; Ergün, 2002) stating that maturation effects learning positively. It can be said that the goals can be understood better İn Germany because students are older than the ones in Turkey. There is not any goal related to Organization Strategy which is one of the metacognition strategies in Turkey while all the goals are related to self-regulation strategies in Germany. It can be stated that Germany's democracy related goals are more appropriate for self-regulation strategies.

In our day instead of acquiring the knowledge inactively, students gain it actively which oblige students to organize his/her learning according to the self-regulation strategies. It also brings into prominence of self-regulation strategies. Recently, the studies indicate that self-regulation strategies underlie present curriculums, moreover curriculums and self-regulation strategies have positive correlations (Zimmerman \& Martinez Pons, 1990; Wolters, Pintrich, \& Karabenick, 2003; Pasternak \& Whitebread, 2010; Cheng, 2011). The students who have better self-regulation strategies skills are more active and constructivist in the learning process; they can control their behaviors, cognitive processes and motivations while having intrinsic motivation (Bono \& Bizri, 2014; Ebadi \& Shakoorzadeh, 2015). Students learnt able to control their self-regulation skills, make self-assessment to be aware of whether they develop or not meanwhile proceeding their goals. If the strategy they are using is not suitable to their desired performance, they re-assess their performance according to their standards. They identify the problem in the strategy and know how to correct it. Students cannot realize their fault clearly or explicitly unless they learn how to assess their learning process (Garner, 1990). Directing students via homework, giving feedback supporting them to find where they made a mistake, giving the some clues indicating how to solve the problems assist students in the learning (Pintrich, 1995).

Some suggestions can make the learning environment a better place for students to learn self-regulation strategies easier. It is seen that Turkey's democracy related unit is missing "organization strategy" related goal. A suitable goal can be added to the curriculum which may support the students better.

Organizing self-regulated learning environment with the suitable activities and goals including observing opportunity for the students, continuously self-assessment skills can make learning process easier and simpler for both countries' students. In such a wide range of goals, it is vital to integrate self-regulation strategies into the curriculums to support the content and goals.

\section{References}

Arsal, Z. (2009). The impact of self-regulation instruction on mathematics achievements and attitudes of elementary school students. International journal of environmental, Science Education, 5(1), 85-103.

Beisthuizen, J. (2008). Does a community of learners foster self-regulated learning? Technology, Pedagogy and Education, 17(3), 183-193. http://dx.doi.org/10.1080/14759390802383769

Bembenutty, H. (2011). Introduction: Self-Regulation of Learning in Postsecondary Education, New Directions for Teaching and Learning, 126, 3-8 Sum 2011. http://dx.doi.org/10.1002/t1.439

Boekaerts, M. (1998). Do culturally rooted self-construals affect students' conceptualization of control over learning? Educational Psychologist, 33, 87-108. http://dx.doi.org/10.1080/00461520.1998.9653293

Bono, K. E., \& Bizri, R. (2014). The Role of Language and Private Speech in Preschoolers' Self-Regulation. Early Child Development and Care, 184(5), 658-670. http://dx.doi.org/10.1080/03004430.2013.813846 
Brown, G. T., Andrade, H. L., \& Chen, F. (2015). Accuracy in student self-assessment: directions and cautions for research. Assessment in Education: Principles, Policy \& Practice, 22(4), 444-457. http://dx.doi.org/10.1080/0969594X.2014.996523

Çepni, S. (2010). Araştırma ve Proje Çalışmalarına Giriş. Trabzon: Üç Yol Kültür Merkezi.

Çetin, O. F. (2015). Mathematics education and democracy education. Educational Research and Reviews, 10(5), 566-576. http://dx.doi.org/10.5897/ERR2015.2081

Cheng, E. C. K. (2011). The role of self-regulated learning in enhancing learning performance. The International Journal of Research and Review, 6(1), 1-16.

Crossley, M., \& Watson, K. (2003). Comparative and international research in education: Globalisation, context and difference. London and New York: Routledge. http://dx.doi.org/10.4324/9780203452745

Dewey, J., \& Archambault, R. D. (1974). John Dewey on education selected writings.

Durmaz, A., \& Avaroğulları, A. K. (2016). Sosyal Bilgiler Derslerinde Etkinlik Uygulamalarının Öğrenci Motivasyonuna Etkisi. Turkish Studies, 11(3). http://dx.doi.org/10.7827/TurkishStudies.9409

Ebadi, S., \& Shakoorzadeh, R. (2015). Investigation of Academic Procrastination Prevalence and Its Relationship with Academic Self-Regulation and Achievement Motivation among High-School Students in Tehran City, International Education Studies, 8(10), 193-199. http://dx.doi.org/10.5539/ies.v8n10p193

Egnor, G. P. (2013). A Case Study of 21st Century Skills in High Achieving Elementary Schools in Pennsylvania (Doctoral dissertation, Indiana University of Pennsylvania).

Erdener, E. (2009). Vygotsky’nin Düşünce ve Dil Gelişimi Üzerine Görüşleri: Piaget’e Eleştirel Bir Bakış. Türk Eğitim Bilimleri Dergisi, 7(1).

Ergün, M. (2009). Eğitim felsefesi. Ankara: Pegem Akademi.

Garner, R. (1990). When children and adults do not use learning strategies: Toward a theory of settings. Review of Educational Research, 60, 517-529. http://dx.doi.org/10.3102/00346543060004517

Gašević, D., Dawson, D., \& Siemens, G. (2015). Let's not forget: Learning analytics are about learning. Springer, 59(1), 64-71. http://dx.doi.org/10.1007/s11528-014-0822-x

Geray, C. (1993). İnsan Hakları İçin Eğitim. İnsan Hakları Ylllı̆ğ, Cilt:XV.

Hantrais, L. (1995). Comparative Research Methods," Social Research Update. England: University of Surrey, Guildford GU2 7XH.

Hwang, W. Y., Hsu, J. L., Shadiev, R., Chang, C. L., \& Huang, Y. M. (2015). Employing self-assessment, journaling, and peer sharing to enhance learning from an online course. Journal of Computing in Higher education, 27(2), 114-133. http://dx.doi.org/10.1007/s12528-015-9096-3

İncirci, A. (2016). The effect of applying the 'writing letter' to learn in English class on the academic achievement, attitude to lesson and metacognition level. Msc Thesis, Bulent Ecevit University: Zonguldak, Turkey.

Kingir, S., Taş, Y., Gök, G., \& Vural, S. S. (2013). Relationships among Constructivist Learning Environment Perceptions, Motivational Beliefs, Self-Regulation and Science Achievement. Research in Science \& Technological Education, 31(3), 205-226. http://dx.doi.org/10.1080/02635143.2013.825594

Loima, J., \& Vibulphol, J. (2016). Learning and motivation in Thailand: A comparative regional study on basic education ninth graders. International Education Studies, 9(1), 31-43. http://dx.doi.org/10.5539/ies.v9n1p31

MEB (2009). Sosyal Bilgiler Öğretim Programi. Retrieved April 7, 2015 from http://ttkb.meb.gov.tr/www/ogretim-programlari/icerik/72

Miller, W. J. (2000). Exploring the source of self-regulated learning: The influence of internal and external comparisons. Journal of Instructional Psychology, 27, 47-52.

Pasternak, D. P., \& David, W. (2010). The Role of Parenting in Children's Self-Regulated Learning," Educational Research Review, 5, 220-242. http://dx.doi.org/10.1016/j.edurev.2010.07.001

Phillips, D., \& Schweisfurth, M. (2014). Comparative and international education: An introduction to theory, method, and practice. London: A\&C Black.

Pintrich, P. R. (1995). Understanding self-regulated learning. In P.R. Pintrich (Ed.), Understanding self-regulated learning (pp. 3-12). San Francisco: Jossey Bass. http://dx.doi.org/10.1002/t1.37219956304 
Pintrich, P. R. (2000). The roal of goal orientation in self-regulated learning. In M. Boekaerts, P. R. Pintrich ve M. Zeidner (Eds.), Handbook of Self-Regulation: Theory, Research and Applications (pp. 452-502) San Diego, CA: Academic Pres

Pintrich, P. R., \& De Groot, E. V. (1990). Motivational and self-regulated learning components of classroom academic performance. Journal of Educational Pyschology, 82(1), 33-40. http://dx.doi.org/10.1037/0022-0663.82.1.33

Riva, S. D., \& Ryan, G. T. (2015). Effect of Self-Regulating Behaviour on Young Children's Academic Success, International Journal of Early Childhood Special Education (INT-JECSE), 7(1), 69-96.

Rizemberg, R., \& Zimmerman, B. J. (1992). Self-regulated learning in gifted students. Roeper Review, 15(2), 98-101. Şişman, M. (2011). Eğitim bilimine giriş. Ankara: Pegem Akademi. http://dx.doi.org/10.1080/02783199209553476

Suzuki, Y. (2015). Self-assessment of Japanese as a second language: The role of experiences in the naturalistic acquisition. Language Testing, 32(1), 63-81. http://dx.doi.org/10.1177/0265532214541885

Wolters. A. C., Pintrich, P., \& Karabenick, A. S. (2003). Assessing academic self-regulated learning. Paper presented at the Conference on Indicators of Positive Development: Definitions, Measures, and Prospective Validity. Washington, DC.

Yıldırım, A., \& Şimşek, H. (2011). Sosyal Bilimlerde Nitel Araştırma Yöntemleri. Ankara: Seçkin yayınları.

Zimmerman, B. J. (1998). Developing self-fulfilling cycles of academic regulation: An analysis of exemplary instructional models. In D. H. Schunk \& B. J. Zimmerman (eds.), Self-regulated learning: from teaching to self-reflective practice (pp. 1-20) New York, NY: The Guilford press.

Zimmerman, B. J. (2000). Attaining Self-Regulation: A Social Cognitive Perspective. Boekaerts, M., Pintrich, P. R., Zeidner, M. (Ed.) Handbook of Self-Regulation (s. 13-39). Academic Press: California. http://dx.doi.org/10.1016/b978-012109890-2/50031-7

This work is licensed under a Creative Commons Attribution 3.0 License. 